\title{
New Palladacycles Derived Acylhydrazones and Hydrazones as Pre-catalyst in Mirozoki-Heck Coupling and Oxyarylations
}

\author{
Vagner D. Pinho, ${ }^{1}$ Raquel Ana. C. Leão, ${ }^{1}$ Arthur Serpa Coelho, ${ }^{1}$ Arthur Eugen \\ Kümmerle, ${ }^{2}$ Paulo R. R. Costa ${ }^{1^{*}}$
}

${ }^{1}$ Laboratório de Química Bioorgânica (LQB), NPPN, CCS, Universidade Federal do Rio de Janeiro, Rio de Janeiro, RJ, Brazil. ${ }^{2}$ Departamento de Química, Instituto de Ciências Exatas Universidade Federal Rural do Rio de Janeiro, Rio de Janeiro, RJ, Brazil.

*prrcosta2011@gmail.com

Keywords: palladacicle, arylation, oxyarylation

\section{INTRODUCTION}

Palladacycle pre-catalyst are considered to be a source of palladium nanoparticles formed in situ and have been used with success, with low catalytic loading, in several coupling reactions. ${ }^{1,2}$

Herein we report the preparation of palladacycles 1 and 2 through electrophilic $\mathrm{C}-\mathrm{H}$ activation of acylhydrazones and hydrazones by reacting them with $\mathrm{Li}_{2} \mathrm{PdCl}_{4}$ in methanol. ${ }^{2}$ Although some hydrazone-based palladacycle are known in the literature. ${ }^{2}$ we describe for the first time their use as catalyst in Heck-Mizoroki arylation and oxyarylation reactions.<smiles>[R]c1c2ccccc2[R](Cl)(C(C)(C)C)n1NC(=O)c1ccccc1</smiles>

a, $\mathrm{R}=\mathrm{H} ;$
b, $\mathrm{R}=\mathrm{Me}$
c, $\mathrm{R}=\mathrm{Ph}$

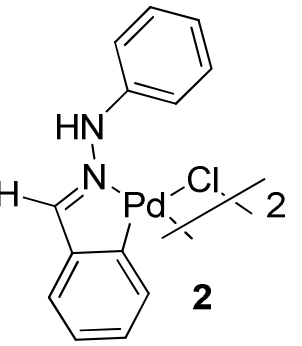

Figure 1. New palladacycles from hydrazones and acylhydrazones.

\section{RESULTS AND DISCUSSION}

Some of our selected results are described in Scheme 1, Table 1. The four palladacycle precatalyst showed in Figure 1 were used in low catalytic loading and promote the Heck-Mizoroki arylation of methyl acrylate by iodobenzene leading to 3 in good chemical yield (entries 1-4). Palladacycles $\mathbf{1 b}$ and $\mathbf{1 c}$ also promoted the arylation of styrene by iodobenzene in moderate chemical yields (entries 5 and 6). Finally, palladacycles 1a-c catalyzed the oxyarylation of dihydronaphthalen by ortho-iodophenol in $\mathrm{MeCN} / \mathrm{H}_{2} \mathrm{O}(1: 3)$ in reasonable chemical yields (entries 7-9). Compound 5 could also be obtained in only $40 \mathrm{~min}$, under microwave irradiation, although in this case the chemical yield decreased (entry 10). ${ }^{3}$

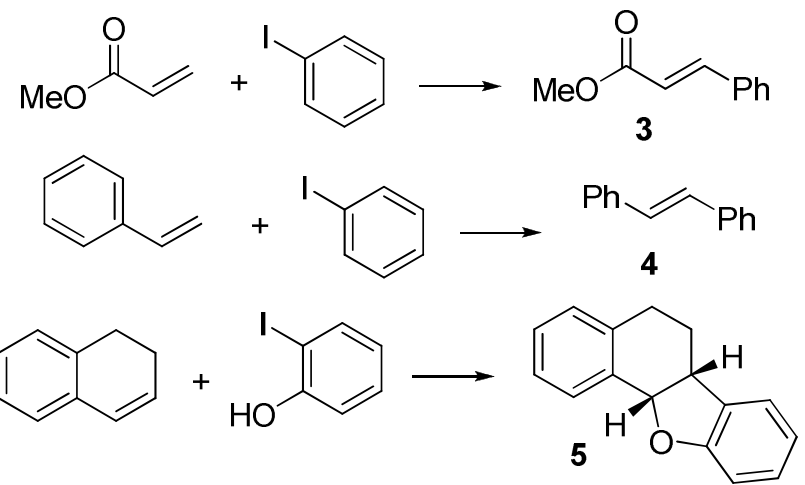

Scheme 1. Palladacycles 1 and 2 as precatalysts in HeckMizoroki arylation and oxyarylation reactions.

Table 1. Yields and main conditions for reaction showed in scheme 1.

\begin{tabular}{|c|c|c|c|}
\hline entry & catalyst & conditions & products \\
\hline 1 & $1 a$ & $\mathrm{DMF}, \mathrm{TEA}, 110^{\circ} \mathrm{C}, 24 \mathrm{~h}$ & $3(80 \%)$ \\
\hline 2 & $1 b^{*}$ & DMF, TEA, $110^{\circ} \mathrm{C}, 24 \mathrm{~h}$ & $3(95 \%)$ \\
\hline 3 & $1 c^{*}$ & DMF, TEA, $110^{\circ} \mathrm{C}, 24 \mathrm{~h}$ & $3(95 \%)$ \\
\hline 4 & $2^{\star \star}$ & DMF, TEA, $110^{\circ} \mathrm{C}, 24 \mathrm{~h}$ & $3(40 \%)^{\#}$ \\
\hline 5 & $1 b^{*}$ & DMF, TEA, $110^{\circ} \mathrm{C}, 24 \mathrm{~h}$ & $4(50 \%)$ \\
\hline 6 & $1 c^{*}$ & $\mathrm{DMF}, \mathrm{TEA}, 110^{\circ} \mathrm{C}, 24 \mathrm{~h}$ & $4(45 \%)$ \\
\hline 7 & $1 a^{\star \star}$ & $\begin{array}{c}\mathrm{MeCN} / \mathrm{H}_{2} \mathrm{O}, \text { DIPEA} \\
120^{\circ} \mathrm{C}, 24 \mathrm{~h}\end{array}$ & $5(50 \%)$ \\
\hline 8 & $1 b^{\star \star}$ & $\begin{array}{c}\mathrm{MeCN} / \mathrm{H}_{2} \mathrm{O}, \mathrm{DIPEA}, \\
120^{\circ} \mathrm{C}, 24 \mathrm{~h}\end{array}$ & $5(55 \%)$ \\
\hline 9 & $1 c^{\star \star}$ & $\begin{array}{c}\mathrm{MeCN} / \mathrm{H}_{2} \mathrm{O}, \mathrm{DIPEA}, \\
120^{\circ} \mathrm{C}, 24 \mathrm{~h}\end{array}$ & $5(56 \%)$ \\
\hline 10 & $1 c^{\star \star}$ & $\begin{array}{l}\mathrm{MeCN} / \mathrm{H}_{2} \mathrm{O}, \mathrm{DIPEA}, \\
\mathrm{MW}, 120^{\circ} \mathrm{C}, 40 \mathrm{~min} .\end{array}$ & $5(37 \%)$ \\
\hline
\end{tabular}

\section{CONCLUSION}

The new palladacycles described herein are promising and other synthetic applications are due in course in our laboratory.

\section{ACKNOWLEDGEMENTS}

FAPERJ, CNPq, CAPES.

\section{REFERENCES}

${ }^{1}$ Botella, L.; Nájera, C., J. Org. Chem.. 2005, 70, 4360.

${ }^{2}$ Le Bras, J.; Muzart, J., Chem. Rev. 2011,111,1170.

${ }^{3}$ Leão, R. A. C.; Pinho, V. D.; Coelho, A. S.; Buarque, C. B.; Moraes, P. F.;

Alonso, D. A.; Nájera, C.; Costa, P. R. R. Eur. J. Org. Chem. in press. 